\title{
Turnover and availability of soil organic carbon under different Mediterranean land-uses as estimated by ${ }^{13} \mathrm{C}$ natural abundance
}

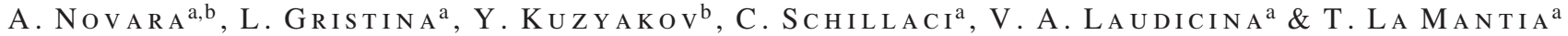 \\ ${ }^{a}$ Dipartimento di Scienze Agrarie e Forestali, University of Palermo, Palermo, 90128, Italy, and boil Science of Temperate Ecosystems, \\ Georg-August-University of Göttingen, Göttingen, 37077, Germany
}

\begin{abstract}
Summary
Soil organic matter (SOM) is an important factor in ecosystem stability and productivity. This is especially the case for Mediterranean soils suffering from the impact of human degradation as well as harsh climatic conditions. We used the carbon (C) exchange resulting from $C_{3}-C_{4}$ and $C_{4}-C_{3}$ vegetation change under field conditions combined with incubations under controlled conditions to evaluate the turnover and availability of soil organic $\mathrm{C}$ under different land-uses. The 40-year succession of Hyparrenia hirta $\mathrm{L}$. ( $\mathrm{C}_{4}$ photosynthesis) after more than 85 years of olive tree (Olea europaea L.; $\mathrm{C}_{3}$ photosynthesis) growth led to the exchange of $54 \%$ of soil organic $\mathrm{C}$ from $\mathrm{C}_{3}$ to $\mathrm{C}_{4}$ forms. In contrast, 21 years of vine (Vitis vinifera $\mathrm{L}$.) growing after $H$. hirta decreased the organic $\mathrm{C}$ content to $57 \%$. Considering this exchange and decrease as well as the periods after the land-use changes, we calculated the mean residence time (MRT) of soil C of different ages. The MRT of $\mathrm{C}$ under grassland dominated by $H$. hirta was about 19 years, but was 180 years under the vineyard. The rates of $\mathrm{C}$ accumulation under the $H$. hirta grassland were about $0.36 \mathrm{Mg} \mathrm{Cha}^{-1}$ year $^{-1}$. In contrast, the rates of $\mathrm{C}$ losses after conversion from natural grassland to a vineyard were 1.8 times greater and amounted to $0.65 \mathrm{MgCha}^{-1}$ year $^{-1}$. We conclude that changes of land use from natural Mediterranean grassland to a vineyard lead to very large $\mathrm{C}$ losses that cannot be compensated for over the same periods.
\end{abstract}

\section{Introduction}

Soil organic matter (SOM) consists of various heterogeneous pools with different stability and turnover rates that play an important role in soil fertility and carbon (C) sequestration (Ussiri \& Johnson, 2003). The level and composition of organic matter pools in soil is determined by the equilibrium between the factors affecting its formation and decomposition (Laudicina et al., 2011). Land-use and land-cover changes modify the turnover of $\mathrm{C}$ and the formation of SOM (Dinesh et al., 2003). Several studies have shown that plant species differ in their capacity to modify soil properties (Vinton \& Burke, 1995; Cornelissen et al., 2004). Thus plant functional characteristics such as growth form, functional traits, biomass allocation, tissue chemistry and lifespan can affect significantly organic matter decomposition and nutrient dynamics in the soil (Carrera et al., 2009). The direction of changes, loss or gain of soil $\mathrm{C}$ stocks after land-use change, depends also on soil properties, climate and management (Novara et al., 2012).

Correspondence: A. Novara. E-mail: agata.novara@unipa.it

Received 22 June 2012; revised version accepted 8 January 2013
In order to assess and predict the effects of land-use change on $\mathrm{C}$ storage, quantitative knowledge of $\mathrm{C}$ stock magnitude and, especially, understanding of mechanisms of SOM stabilization for each specific environment are necessary.

Very few studies have focused on the effect of land-use change on turnover and availability of $\mathrm{C}$ in Mediterranean ecosystems (Gavrichkova et al., 2010). Mediterranean areas in recent centuries have been subjected to a substantial human impact, with intensive cultivation altering the structure and functions of soil, leading to erosion and degradation. Such strongly degraded lands have been removed from agricultural use because of reduced economic benefits and left for succession of (semi)natural vegetation developing to 'macchia' and 'garrigue' vegetation (Loumou \& Giourga, 2003). Such semi-natural vegetation succession contributes to improvement of soil properties over the longer term and also changes the $\mathrm{C}$ stocks. Despite some studies on $\mathrm{C}$ sequestration after natural vegetation succession in abandoned land in other areas (Kurganova et al., 2010), Mediterranean areas are strongly under-represented.

To identify mechanisms controlling changes in $\mathrm{C}$ pools associated with land use and land cover, various physical 
fractionation methods have been used (Jolivet et al., 2003). Physical fractionation studies of SOM have revealed that soil aggregation, reducing accessibility of microbial biomass to particulate organic matter, contributes to physical protection and thus stabilization of SOM (von Lützow et al., 2006). It was observed that a greater $\mathrm{OM}$ content and greater mineralization rates are usually associated with the macroaggregate fraction. On the other hand, the OM associated with microaggregates may be more protected physically and more recalcitrant biochemically (Dorodnikov et al., 2011). However, fractionation provides information on the net change in $\mathrm{C}$ only and not on the mineralization of organic matter originating from old vegetation and the incorporation of plant residue from the new land use (Shang \& Tiessen, 2000). Alternatively, the turnover of SOM can be evaluated with approaches based on natural differences in $\delta^{13} \mathrm{C}$ of plants with $\mathrm{C}_{3}$ and $\mathrm{C}_{4}$ photosynthesis (Schneckenberger $\&$ Kuzyakov, 2007). This isotopic approach permits calculation of organic $\mathrm{C}$ pools derived from old (in most studies, $\mathrm{C}_{3}$ ) and new (in most studies, $\mathrm{C}_{4}$ ) vegetation because the two types of vegetation differ in their $\delta^{13} \mathrm{C}$ according to $\mathrm{C}_{3}$ and $\mathrm{C}_{4}$ photosynthetic pathways (Werth \& Kuzyakov, 2008).

Our study highlighted the effects of land-use changes on SOC stocks and organic matter dynamics in Mediterranean ecosystems using natural differences in $\delta^{13} \mathrm{C}$ of plants with $\mathrm{C}_{3}$ and $\mathrm{C}_{4}$ photosynthesis. In contrast to nearly all previous studies, we used land-use changes in both directions $\left(\mathrm{C}_{3} \rightarrow \mathrm{C}_{4}\right.$ and $\left.\mathrm{C}_{4} \rightarrow \mathrm{C}_{3}\right)$. A unique research area with a history of vegetation change from a $\mathrm{C}_{3}$-olive (Olea europaea $\mathrm{L}$.) plantation to a $\mathrm{C}_{4}$-Hyparrenia hirta L. grassland and from $\mathrm{C}_{4}-H$. hirta grassland to a $\mathrm{C}_{3}$-vineyard (Vitis vinifera L.) was chosen to follow changes in both directions. It is important to note that these vegetation changes occurred at the same location with identical climatic conditions and the same soil type. This is an important prerequisite for using $\delta^{13} \mathrm{C}$ signatures to calculate mean residence time (MRT) of various SOM pools, this being the spatial variation of soil $\delta^{13} \mathrm{C}$ in relation to $\mathrm{C}$ input and soil texture (Bai et al., 2012). H. hirta is widely distributed in the Mediterranean area (Botha \& Russell, 1988), North Africa and the Middle East (Chejara et al., 2008) from sea level up to $600 \mathrm{~m}$ above sea level. It is a typical species of degraded areas after disturbance such as fire or intensive grazing with fast growth: this means that $H$. hirta grasslands are very suitable for studying turnover and stabilization of SOM in semiarid environments.

$H$. hirta produces much above- and below-ground biomass, especially under water limitation as is common in Mediterranean areas in summer. As is common for grasses, its contribution to below-ground $\mathrm{C}$ input is greater than that of herbs, shrubs and trees. Such accumulation and input of $\mathrm{C}$ into the soil under $H$. hirta is, furthermore, better stabilized during periods of microbial dormancy during summer. Moreover, natural grasses such as $H$. hirta strongly decrease and even stop erosion, and consequently contribute to maintenance of $\mathrm{C}$ stocks in the soil.

We hypothesize that such land-use changes in a typical Mediterranean environment affect $\mathrm{C}$ dynamics in soil and the natural recovery of soil fertility and functions. Our objectives were to (i) assess the change in SOC stocks when agricultural land-use is followed by native vegetation and vice versa, (ii) estimate SOM turnover during secondary succession in an agricultural abandoned land $\left(\mathrm{C}_{3}-\mathrm{C}_{4}\right.$ soil $)$ and under an agricultural crop $\left(\mathrm{C}_{4}-\mathrm{C}_{3}\right.$ soil $)$ and (iii) reflect on the importance of various soil organic fractions in the turnover and stabilization of SOM by common land uses in the Mediterranean.

\section{Material and methods}

\section{Study and sampling area}

The study was carried out on the south side of Inici Mountain, in Sicily, Italy $\left(37^{\circ} 57^{\prime} 45^{\circ} \mathrm{N}, 12^{\circ} 51^{\prime} 34^{\circ} \mathrm{E}\right)$ (Figure 1). The area is semiarid (Thornthwaite \& Mather, 1955) with a typical Mediterranean climate: most of the annual mean precipitation (409 mm) falls between October and February; monthly average temperatures range from $12^{\circ} \mathrm{C}$ (January) to $25^{\circ} \mathrm{C}$ (August). The underlying geology is the result of tectonic overlaying of various carbonate, carbonate-silicoclastic and terrigenous geological bodies, which are formed in the upper Triassic-middle Tortonian. The soil in the study area is classified as a Regosol (WRB, 2006) with $60 \%$ clay, $25 \%$ silt and $15 \%$ sand.

A secondary succession was selected on a south-facing gentle slope $(2-5 \%)$ represented by an olive grove, H. hirta grassland and a vineyard (Figure 1). The area was completely covered by olives for at least 75 years until 1971, when a wildfire burnt half of the olive grove area. The burnt area was left to undergo secondary succession to $\mathrm{H}$. hirta $\left(\mathrm{C}_{4}\right.$ photosynthesis) grassland and in 1990 half of the H. hirta grassland was converted to a vineyard. The dates of the fire event and the vineyard planting were determined using aerial photographs. Environmental factors such as geological substrate, soil texture, slope, soil type and aspect can be regarded as homogeneous for all the land covers in the succession. Three soil samples were collected at 0-15$\mathrm{cm}$ depth for each stage of succession. To reduce the error tolerance to less than $\pm 5 \%, 24 \mathrm{~kg}$ of soil was collected per sample and mixed. The soil was air-dried and passed through a 2-mm sieve.

\section{Soil analyses and aggregate-size fractionation}

Wet aggregate-size fractions with no prior chemical dispersion, were isolated by mechanical shaking of $100 \mathrm{~g}$, air-dried fine earth on a column with sieves of 1000, 250, 63 and $25 \mu \mathrm{m}$ using a Shaker AS 200 Sieve (RETSCH analytical, Haan, Germany) (203-mm sieves, amplitude of $2 \mathrm{~cm}$, frequency of $1.6 \mathrm{~Hz}$ and a water flux of 2 litres minute ${ }^{-1}$ ). After the physical fractionation, we distinguished four main aggregate-size fractions: 1000-2000, 250-1000, 63-250 and $<63 \mu \mathrm{m}$.

For $\delta^{13} \mathrm{C}$ analysis of $\mathrm{CO}_{2}-\mathrm{C}$, carbonates in $\mathrm{NaOH}$ were precipitated with $1 \mathrm{ml} 5.5 \mathrm{M} \mathrm{CaCl}_{2}$ (formation of a $\mathrm{CaCO}_{3}$ precipitate) and immediately washed/centrifuged three times with degassed deionized water before being dried at $55^{\circ} \mathrm{C}$ for 24 hours. 


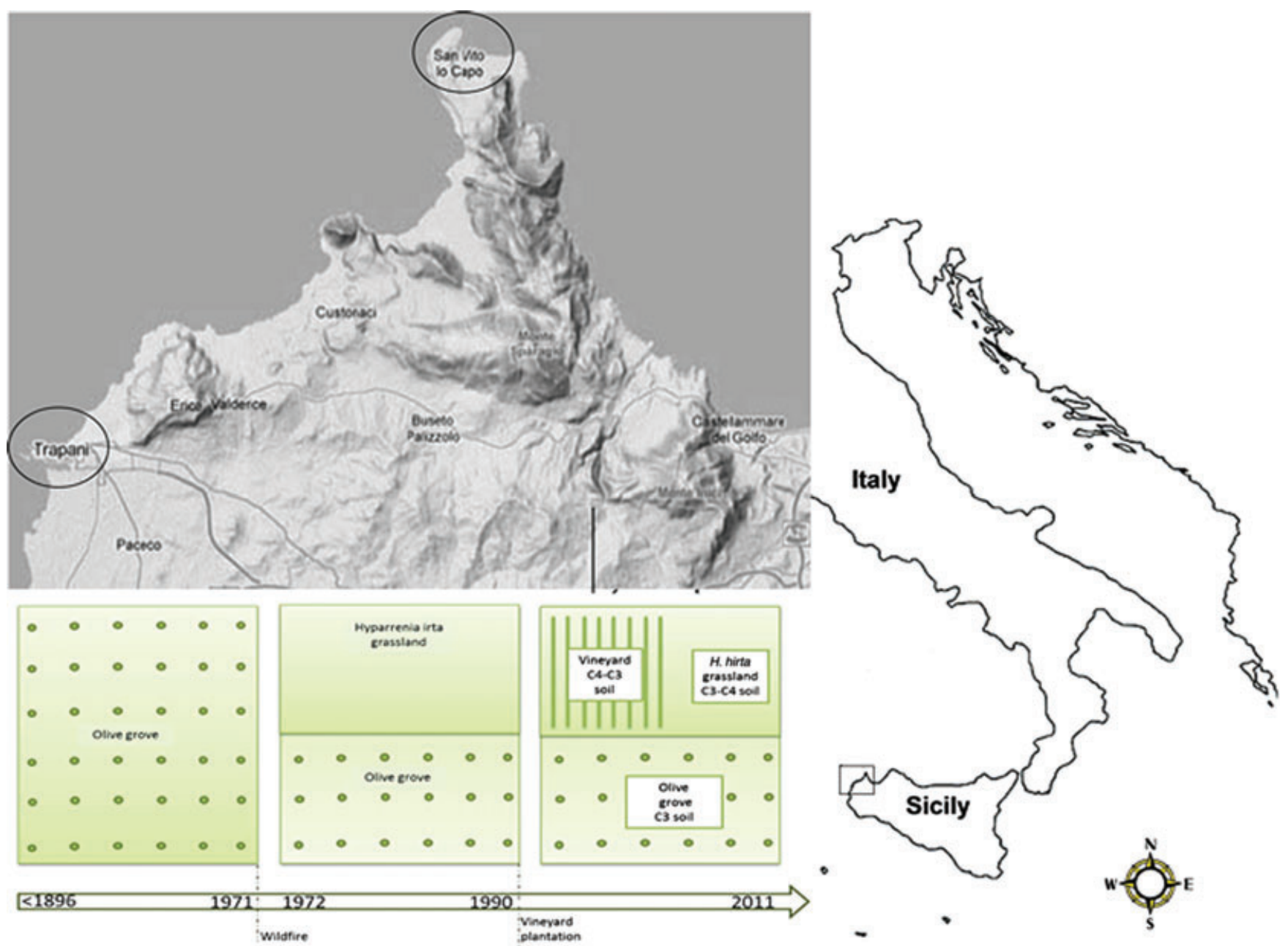

Figure 1 Schema of the experiment with three land-use types, secondary vegetation succession and periods of $\mathrm{C}_{3}$ and $\mathrm{C}_{4}$ residues input to study site in Sicily (IT).

For each aggregate fraction, the relative mass distribution, the $\mathrm{C}$ content and $\delta{ }^{13} \mathrm{C}$ signature were measured. Soil OC content was measured using an elemental analyser (NA1500 Carlo Erba, Milan, Italy).

Soil C stock $\left(\mathrm{Mg} \mathrm{ha}^{-1}\right)$ was calculated as:

$$
\mathrm{C}_{\text {stock }}\left(\mathrm{Mg} \mathrm{ha}^{-1}\right)=\mathrm{BD} \times \mathrm{Ccon} \times \mathrm{D} \times \mathrm{CF}_{\text {coarse }},
$$

where $\mathrm{C}_{\mathrm{con}}$ is carbon content (\%), BD is bulk density $\left(\mathrm{Mg} \mathrm{m}^{-3}\right)$, $\mathrm{D}$ is depth thickness $(\mathrm{m})$ and $\mathrm{CF}$ is a correction factor for stone content (1- [gravel \%+stone \%]/100). Bulk density was measured by using the volume of the collected sample and the mass of dry soil in the sample (Blake \& Hartge, 1986).

\section{Incubation procedure}

In the three soil land-use types (an olive grove $\left[\mathrm{C}_{3}\right]$, $\mathrm{H}$. hirta grassland $\left[\mathrm{C}_{3}-\mathrm{C}_{4}\right]$ and a vineyard $\left.\left[\mathrm{C}_{4}-\mathrm{C}_{3}\right]\right) \mathrm{C}$ mineralization dynamics was investigated on three sub-samples for each replicate (nine samples) by incubating $10 \mathrm{~g}$ soil at $50 \% \mathrm{WHC}$ in $125-\mathrm{ml}$ glass flasks at $25^{\circ} \mathrm{C}$ for 32 days. Soil respiration rate was determined seven times (over 32 days), measuring the $\mathrm{CO}_{2}$ accumulated in the headspace of the flasks by a gas chromatograph equipped with a thermal conductivity detector (TCD). Twenty-four hours before the $\mathrm{CO}_{2}$ sampling, all of the flasks were ventilated with fresh air and then sealed with rubber stoppers. Carbon dioxide sampling started 1 week after the start of the incubation to allow the soil to equilibrate after handling (Robertson et al., 1999). The amount of $\mathrm{CO}_{2}$ evolved from each flask was calculated according to Zibilske (1994).

\section{Stable carbon isotopic analysis and calculations of old and new $C$}

The ${ }^{13} \mathrm{C}:{ }^{12} \mathrm{C}$ ratio of bulk soil, SOM pools and $\mathrm{CO}_{2}$ released during incubation was measured using an EA-IRMS (elemental analyser isotope ratio mass spectrometer Carlo Erba $\mathrm{Na} 1500$, model Isoprime (2006), Manchester, UK). The reference material 
used for analysis was IA-R001 (Iso-Analytical Limited, Crewe, $\mathrm{UK}$, wheat flour standard, $\delta^{13} \mathrm{C}_{\mathrm{V}-\mathrm{PDB}}=-26.43 \%$ ). IA-R001 is traceable to IAEA-CH-6 (cane sugar, $\delta^{13} \mathrm{C}_{\mathrm{V}-\mathrm{PDB}}=-10.43 \%$ ). IA-R001, IA-R005 (Iso-Analytical Limited beet sugar standard, $\delta^{13} \mathrm{C}_{\mathrm{V}-\mathrm{PDB}}=-26.03 \%$ ) and IA-R006 (Iso-Analytical Limited cane sugar standard, $\delta^{13} \mathrm{C}_{\mathrm{V}-\mathrm{PDB}}=-11.64 \%$ o) were used as quality control for the analysis. The $\mathrm{C}$ isotope results are expressed in delta $(\delta)$ notation and $\delta^{13} \mathrm{C}$ values are reported in parts per thousand (\%o) relative to the Vienna Pee Dee Belemnite (VPDB) standard.

Natural abundance of $\delta^{13} \mathrm{C}$ was used to determine the proportion of $\mathrm{C}$ in SOM that was derived from the new crop and how much $\mathrm{C}$ remained from the previous crop in each soil aggregate size fraction. These proportions were calculated with the mixing equation (Gearing, 1991):

New carbon derived $(N c d)=\frac{\delta^{13} C_{\text {new }}-\delta^{13} C_{\text {old }}}{\delta^{13} C_{\text {biomass new species }}-\delta^{13} C_{\text {old }}}$

and

$$
\text { Old Carbon derived }(\mathrm{Ocd})=1-\mathrm{Ncd}
$$

where Ncd is the fraction of $\mathrm{C}$ derived from new vegetation ( $H$. hirta and/or vines), $\delta^{13} \mathrm{C}_{\text {new }}$ is the isotope ratio of the soil sample, $\delta^{13} \mathrm{C}_{\text {biomass new species }}$ is the isotope ratio of the colonizing species $(-13.3 \pm 0.15 \%$ o for $H$. hirta and $28 \pm 0.09 \%$ for vines) and $\delta^{13} \mathrm{C}_{\mathrm{old}}$ is the isotopic ratio of the previous vegetation type. The $\delta^{13} \mathrm{C}$ values of soil under $\mathrm{H}$. hirta are different from $\delta{ }^{13} \mathrm{C}$ of $\mathrm{H}$. hirta biomass. The portion of old $\mathrm{C}$ derived under vines does not correspond to soil $\mathrm{C}_{4}-\mathrm{C}$ amount. Under the vineyard, SOC contains residue of $\mathrm{C}_{3}-\mathrm{C}$ from previous land use (olive grove). Therefore, we calculated the percentage of $\mathrm{C}_{3}-\mathrm{C}$ and $\mathrm{C}_{4}-\mathrm{C}$ of the old $\mathrm{C}$ derived using the proportions of $\mathrm{C}_{3}-\mathrm{C}$ and $\mathrm{C}_{4}-\mathrm{C}$ under the previous land-use.

\section{Estimation of $C$ turnover}

The $\mathrm{C}$ turnover in the succession of natural vegetation was estimated with two approaches: (i) $\delta^{13} \mathrm{C}$ isotopic signature shift in SOM after $\mathrm{C}_{3}-\mathrm{C}_{4}$ and $\mathrm{C}_{4}-\mathrm{C}_{3}$ vegetation change (Werth \& Kuzyakov, 2008) and (ii) $\mathrm{C}$ mineralization during incubation experiments (Blagodatskaya et al., 2011).

For the first approach, the turnover of SOM (mean residence time in years, MRT) was determined as a reciprocal of the rate constant (k) of first order decay (Equation (4)) (Balesdent \& Mariotti, 1996; Derrien \& Amelung, 2011):

$$
\mathrm{k}=-\ln (1-\mathrm{Ncd}) / \text { years since disturbance. }
$$

The MRT for $\mathrm{C}$ in soil under $H$. hirta and the vineyard was calculated as the weighted mean MRT of new and old SOM. The mass of new $\mathrm{C}$ added by plants to the soil was calculated both for bulk soil and for each aggregate-size fraction.
In the second approach, the amount of total $\mathrm{C}$ mineralized was calculated by the linear interpolation of two neighbouring measured rates and the numerical integration over time as reported in the following equation:

$$
\mathrm{CO}_{2}-\mathrm{C}=\sum_{i}^{n}\left[\left(r_{i}+r_{i+1}\right) \times \frac{d}{2}\right]+\ldots+\left[\left(r_{n-1}+r_{n}\right) \times \frac{d}{2}\right]
$$

where $i$ is the date of the first measurement of $\mathrm{CO}_{2}-\mathrm{C}$ rate, $n$ is the date of the last measurement of $\mathrm{CO}_{2}-\mathrm{C}$ rate, $r$ is the $\mathrm{CO}_{2}-\mathrm{C}$ rate expressed as $\mathrm{mg} \mathrm{CO}_{2}-\mathrm{C} \mathrm{kg}^{-1}$ dry soil and $d$ is the number of days between the two consecutive $\mathrm{CO}_{2}$ rate measurements $(3,4,4,7$, 4, 7 and 7 days corresponding to the days after the incubation start of $3,7,11,18,22,29$ and 36 , respectively). The $\mathrm{C}$ mineralization rate was expressed as $\mathrm{mg} \mathrm{C} \mathrm{g}^{-1} \mathrm{SOC} \mathrm{day}^{-1}$ and was fitted to the following first-order decay function:

$$
\text { Mineralized } \mathrm{C}=\mathrm{C}_{\mathrm{r}} \mathrm{e}^{-\mathrm{kt}}
$$

where $\mathrm{C}_{\mathrm{r}}$ is the readily mineralizable $\mathrm{C}$ at time zero (the intercept value), $\mathrm{k}$ is the decay rate constant and $\mathrm{t}$ is time.

\section{Calculations}

Corrections for dilution by atmospheric $\mathrm{CO}_{2}$ in the incubation jars were made with the following equation:

$$
\delta^{13} \mathrm{CO}_{2} \text { measured }=\mathrm{f}+\delta^{13} \mathrm{CO}_{2} \text { atm }+(1-\mathrm{f}) \times \delta^{13} \mathrm{CO}_{2} \text { sample },
$$

such that:

$$
\delta^{13} \mathrm{CO}_{2 \text { sample }}=\delta^{13} \mathrm{CO}_{2 \text { measured }}-\mathrm{f} \times \delta^{13} \mathrm{CO}_{2} \mathrm{~atm}
$$

where $\mathrm{f}$ is the fraction of the sample value contributed by atmospheric $\mathrm{CO}_{2}$, which is calculated using a background concentration of $450 \mu 11^{-1} \mathrm{CO}_{2}$ in the incubation jars. $\delta^{13} \mathrm{CO}_{2}$ measured is the measured isotopic ratio, $\delta^{13} \mathrm{CO}_{2}$ sample is the undiluted isotopic ratio of microbial respiration, and the $\delta_{13} \mathrm{CO}_{2 \mathrm{~atm}}$ is the isotopic ratio of measured atmospheric (laboratory air) $\mathrm{CO}_{2}$.

Fractionation was determined solving the following equation system for $x$ :

$$
\begin{aligned}
{\left[\mathrm{CO}_{2}\right]_{\mathrm{m}} \times \delta^{13} \mathrm{C}_{\mathrm{m}}=} & x \times\left[\mathrm{CO}_{2}\right]_{\mathrm{O}} \times \delta^{13} \mathrm{C}_{\mathrm{O}}+(1-x) \\
& \times\left[\mathrm{CO}_{2}\right]_{\mathrm{H}} \times \delta^{13} \mathrm{C}_{\mathrm{H}} \\
{\left[\mathrm{CO}_{2}\right]_{\mathrm{m}}=} & x \times\left[\mathrm{CO}_{2}\right]_{\mathrm{O}}+(1-\mathrm{x}) \times\left[\mathrm{CO}_{2}\right]_{\mathrm{H}}
\end{aligned}
$$

where $x$ is the olive soil's $\mathrm{CO}_{2}$ production, $\left[\mathrm{CO}_{2}\right]_{\mathrm{m}}$ is the measured $\mathrm{CO}_{2},\left[\mathrm{CO}_{2}\right]_{\mathrm{O}}$ is the olive soil $\mathrm{CO}_{2}$ and $\left[\mathrm{CO}_{2}\right]_{\mathrm{H}}$ represents the $H$. hirta soil $\mathrm{CO}_{2}$. Values of $-27.5,-13.3 \%$ and $-28.0 \%$ were used as $\delta^{13} \mathrm{C}_{\mathrm{O}}, \delta^{13} \mathrm{C}_{\mathrm{H}}$ and $\delta^{13} \mathrm{C}_{\mathrm{V}}$, respectively. The equivalent procedure was carried out for the second succession step ( $H$. hirta compared with vineyard). 


\section{Statistical analysis}

The data for total soil C, new crop-derived C, C stock and content for each fraction were analysed by analysis of variance (ANOVA) after assessing variance homogeneity. Differences between the means were tested with the LSD test at $P<0.05$. Standard errors for regression parameters were calculated. SAS statistical software was used (SAS Institute, 2001).

\section{Results}

SOC stocks in bulk soil and aggregate fractions

Carbon content during secondary succession increased by more than $39 \%$ after conversion from an olive grove to $H$. hirta grassland. In contrast, the conversion of natural grassland to a vineyard after 21 years resulted in an SOC depletion of $32 \%$. Among the land uses, the largest SOC content was found under H. hirta $\left(25 \pm 3 \mathrm{Mgha}^{-1}\right)$, followed by the olive plantation $\left(18 \pm 5 \mathrm{Mgha}^{-1}\right)$ and vineyard $\left(17 \pm 3 \mathrm{Mgha}^{-1}\right)$, showing a strong decrease in $\mathrm{C}$ content in the bulk soil under cultivation.

The aggregate fraction $<63 \mu \mathrm{m}$ was the most abundant because of a large clay content: this was followed in order in the $63-250,250-1000$ and 1000-2000- $\mu \mathrm{m}$ fractions (Figure 2). In all fractions, statistically significant differences were found between $H$. hirta grassland and agricultural land use (olives and vines), except for the 250-1000- $\mu \mathrm{m}$ fraction. Under all land uses, the mass contribution of each aggregate size fraction to the bulk soil increased with the decrease in aggregate sizes. However, no significant differences were found for the two biggest aggregate fractions (Figure 2).

In the olive grove and vineyard the largest $\mathrm{C}$ content was recorded in the $63-250 \mu \mathrm{m}$ fraction $\left(12.1\right.$ and $14.1 \mathrm{mg} \mathrm{Cg}^{-1}$, respectively) while the largest content under $\mathrm{H}$. hirta was measured in the $1000-2000-\mu \mathrm{m}$ fraction (15.2 $\mathrm{mg} \mathrm{Cg}^{-1}$ ) (Figure 3). On average more than $50 \%$ of bulk SOC was contained in the smallest fraction $(<63 \mu \mathrm{m})$ because of the combined effects of the largest amount of fine aggregate fractions in the soils and its greater $\mathrm{C}$ content.

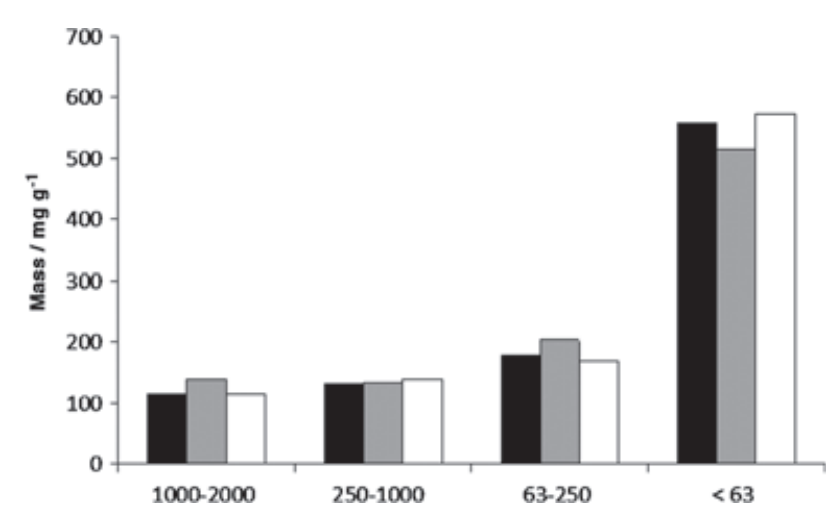

Figure 2 Mass of aggregate size fractions in soil under the olive grove (black columns), vineyard (white columns) and H. hirta grassland (grey columns).

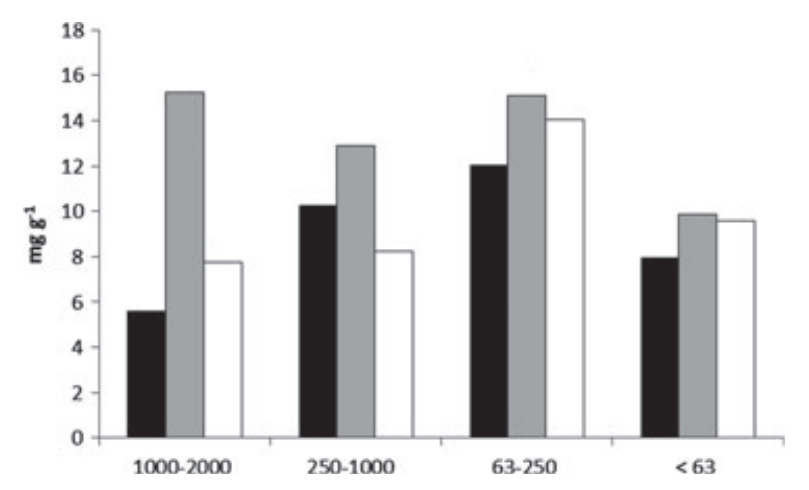

Figure 3 Carbon content in aggregate size fractions in soil under the olive grove (black columns), vineyard (white columns) and H. hirta grassland (grey columns).

\section{$\delta^{13} \mathrm{C}$ signature in bulk soil and aggregate size fractions}

$\delta^{13} \mathrm{C}$ values of bulk soil and aggregate size fractions were significantly $(P<0.05)$ affected by land use, and were largest in $H$. hirta grassland $\left(\mathrm{C}_{3}-\mathrm{C}_{4}\right.$ soil $)$, followed by the vineyard $\left(\mathrm{C}_{4}-\mathrm{C}_{3}\right.$ soil) and the olive grove $\left(\mathrm{C}_{3}\right.$ soil) (Table 1 and 2$)$. Under each land use, the differences among the fractions were small, except in the case of the smallest. The coarsest fraction had similar $\delta^{13} \mathrm{C}$ values to that of plant residues, while in the smallest fraction the $\delta^{13} \mathrm{C}$ value became less negative for cultivated $\mathrm{C}_{3}$ soil and, in contrast, more negative in natural grassland. The average $\delta^{13} \mathrm{C}$ values among the aggregate fractions were $0.73,1.23$ and $0.48 \%$ o for the olive grove, $H$. hirta grassland and vineyard respectively.

The effect of land-use change (from $\mathrm{C}_{3}$ to $\mathrm{C}_{4}$ and from $\mathrm{C}_{4}$ to $\mathrm{C}_{3}$ ) on $\mathrm{C}$ stock was demonstrated by $\mathrm{C}$ derived from $H$. hirta and from vines (Table 1). After 40 years of $H$. hirta grassland, $80 \%$ of the $\mathrm{C}$ still originated from the olive grove, whereas in the vineyard only $6 \%$ of the $\mathrm{C}$ had a $H$. hirta origin after 21 years. The landuse change from olives to $H$. hirta led to an increase of $2.7 \%$ of $\mathrm{C}_{4}-\mathrm{C}$, but the stock of $\mathrm{C}$ derived from olives $\left(\mathrm{C}_{3}\right)$ was mostly preserved. In $H$. hirta grassland most of the $\mathrm{C}_{3}-\mathrm{C}$ was contained in the smallest aggregates and therefore this portion was stable (Figure 4). The shift from $H$. hirta to vines led to the loss of $2.08 \mathrm{~g} \mathrm{~kg}^{-1}$ of $\mathrm{C}_{3}-\mathrm{C}$ and $1.8 \mathrm{~g} \mathrm{~kg}^{-1}$ of $\mathrm{C}_{4}-\mathrm{C}$ (Figure 4). Most of the $\mathrm{C}_{3}-\mathrm{C}$ loss when vines followed $H$. hirta was recorded in the biggest aggregates.

\section{Fluxes and sources of $\mathrm{CO}_{2}$ by incubation}

During 32 days of incubation, the largest $\mathrm{CO}_{2}$ emission rate was recorded from the olive grove soil and ranged between $47 \mathrm{mg}$ $\mathrm{CO}_{2}-\mathrm{C} \mathrm{kg}^{-1} \mathrm{day}^{-1}$ (first day of incubation) and $14.7 \mathrm{mg} \mathrm{CO}-\mathrm{C}$ $\mathrm{kg}^{-1} \mathrm{day}^{-1}$ (after 32 days). This was followed by the soil under vines (from 37 to $13.05 \mathrm{mg} \mathrm{CO}_{2}-\mathrm{C} \mathrm{kg}^{-1} \mathrm{day}^{-1}$ ) and $H$. hirta (25.05 to $8.86 \mathrm{mg} \mathrm{CO}_{2}-\mathrm{C} \mathrm{kg}^{-1} \mathrm{day}^{-1}$ ) (Figure 5). The total $\mathrm{C}$ mineralized from soil over 1 month was greater under the vineyard and olive grove (592 \pm 162 and $535 \pm 82 \mathrm{mg} \mathrm{kg}^{-1}$, respectively) than in the $H$. hirta soil $\left(383 \pm 27 \mathrm{mg} \mathrm{kg}^{-1}\right)$. The $\delta^{13} \mathrm{C}$ of the $\mathrm{CO}_{2}$ evolved during the incubation ranged between $-26.5 \%$ and 
Table $1 \delta^{13} \mathrm{C}(\% o)$ and portion of $\mathrm{C}_{3}-\mathrm{C}$ and $\mathrm{C}_{4}-\mathrm{C}$ in bulk soil and aggregate size fractions

\begin{tabular}{|c|c|c|c|c|c|c|c|}
\hline & \multicolumn{3}{|l|}{$\delta^{13} \mathrm{C}$} & \multicolumn{4}{|c|}{ Carbon distribution } \\
\hline & $\begin{array}{l}\text { Olive grove } \\
\mathrm{C}_{3} \text { soil }\end{array}$ & $\begin{array}{l}\text { H. hirta } \\
\mathrm{C}_{3}-\mathrm{C}_{4} \text { soil }\end{array}$ & $\begin{array}{l}\text { Vineyard } \\
\mathrm{C}_{4}-\mathrm{C}_{3} \text { soil }\end{array}$ & $\mathrm{C}_{3}-\mathrm{C}$ & $\mathrm{C}_{4}-\mathrm{C}$ & $\mathrm{C}_{4}-\mathrm{C}$ & $\mathrm{C}_{3}-\mathrm{C}$ \\
\hline Bulk soil & -27.14 & -24.37 & -26.81 & 0.20 & 0.80 & 0.064 & 0.936 \\
\hline $1000-2000 \mu \mathrm{m}$ & -27.14 & -24.59 & -26.81 & 0.18 & 0.82 & 0.063 & 0.937 \\
\hline $250-1000 \mu \mathrm{m}$ & -27.71 & -24.58 & -26.89 & 0.21 & 0.79 & 0.069 & 0.931 \\
\hline
\end{tabular}

Table 2 Summary results for SOC (a) and $\delta 13 \mathrm{C}$ from ANOvA (b)

\begin{tabular}{lcllll}
\hline & $\begin{array}{l}\text { Degrees } \\
\text { freedom }\end{array}$ & $\begin{array}{l}\text { Sum } \\
\text { squares }\end{array}$ & $\begin{array}{l}\text { Mean } \\
\text { square }\end{array}$ & $F$ ratio & $P$ \\
\hline Land use & 2 & 1.8835 & 0.94176 & 4.02 & 0.02 \\
Replicas & 2 & 0.1520 & 0.07602 & 0.32 & 0.7 \\
Aggregate fraction (residual) & 428 & 2.0918 & 0.52295 & 2.23 & 0.09 \\
& Degrees & Sum & Mean & & \\
(b) Source & freedom & squares & square & $F$ ratio & $P$ \\
\hline Land use & 2 & 69.8152 & 34.9076 & 72.96 & 0.00 \\
Replicas & 2 & 3.9760 & 1.9880 & 4.16 & 0.02 \\
Aggregate fraction (residual) & 428 & 0.1843 & 0.0460 & 0.10 & 0.04 \\
\hline
\end{tabular}

$-25.0 \%$ in the olive grove, from $-26.0 \%$ to $-23.5 \%$ in the vineyard soil and from $-24.0 \%$ to $-21.5 \%$ in the $H$. hirta soil (Figure 6). The $\delta^{13} \mathrm{C}$ values of $\mathrm{CO}_{2}$ from all soils were strongly depleted during the first week of incubation. The contribution of recent $\mathrm{C}_{4}$ to $\mathrm{CO}_{2}$ flux increased from $65 \%$ at the beginning to $91 \%$ at the last stage (32 days) of incubation in $\mathrm{C}_{3}-\mathrm{C}_{4}$ soil (Figure 7), while it ranged from 40 to $84 \%$ in $\mathrm{C}_{4}-\mathrm{C}_{3}$ soil. The ratio of $\mathrm{C}_{3}-\mathrm{C}$ in evolved $\mathrm{CO}_{2}$ to that in $\mathrm{SOM}$ was 0.37 for $\mathrm{C}_{3}-\mathrm{C}_{4}$ soil and 0.21 for $\mathrm{C}_{4}-\mathrm{C}_{3}$ soil (Figure 8).

\section{Carbon turnover}

Using the first approach, MRT of bulk soil was estimated as 19 and 183 years for $H$. hirta and olive grove SOM, respectively. The MRT increased with decreasing aggregate size under both land uses. In the fraction $<25 \mu \mathrm{m}$ the MRT was 37 and 193 years, respectively, for the $H$. hirta and olive grove soils. The MRT calculated by the second approach, based on released $\mathrm{CO}_{2}$, was 30 , 17 and 22 days for $H$. hirta, olive and vineyard soils, respectively. These values reflect the MRT of easily available $\mathrm{C}$ in soil that was involved in decomposition within 1 month.

\section{Discussion}

\section{Land-use change and C stocks}

SOC content was very sensitive to land-use changes. Forty years after the abandonment of the olive grove and subsequent natural vegetation succession, the $\mathrm{OC}$ in bulk soil increased
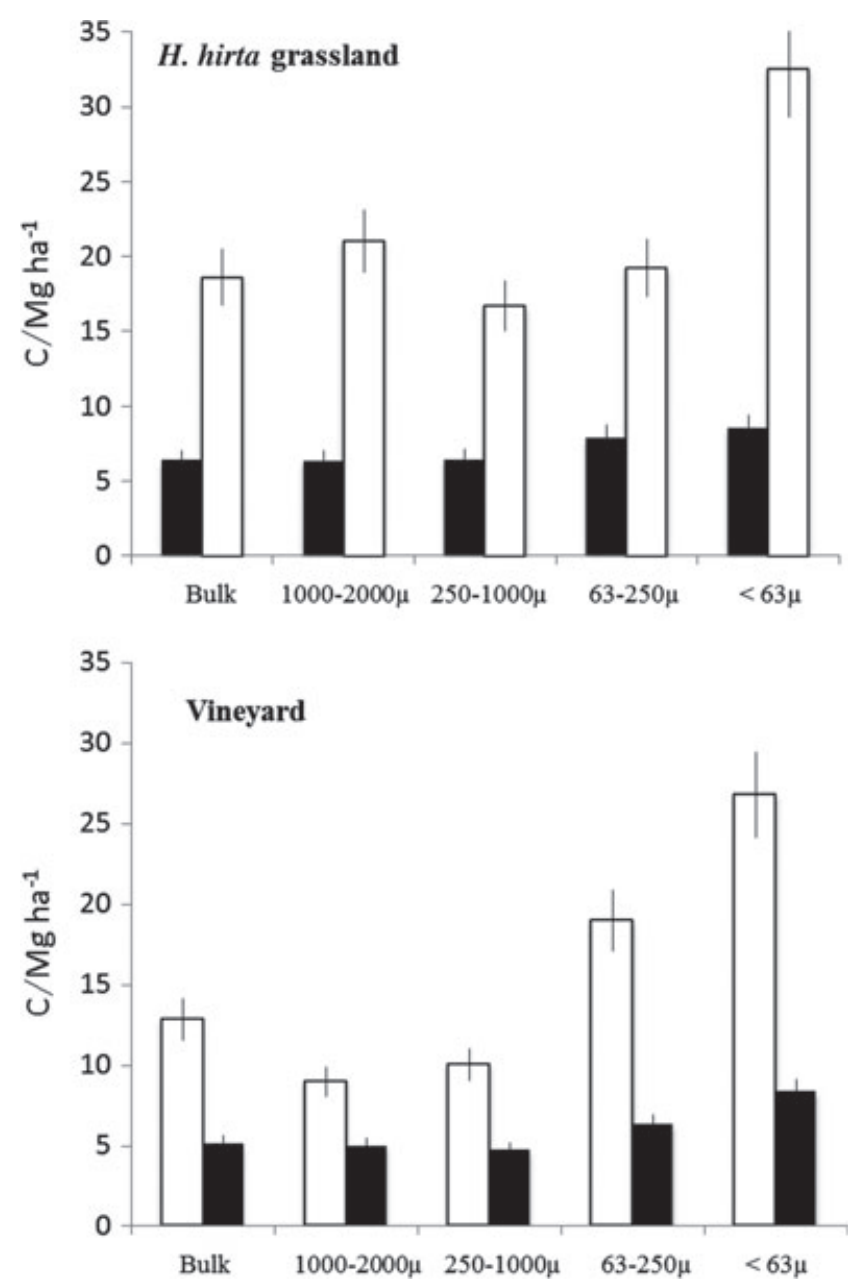

Figure 4 Content of $\mathrm{C}_{3}-\mathrm{C}$ (white histograms) and $\mathrm{C}_{4}-\mathrm{C}$ (black histogram) in bulk soil and for each particle size-fraction in H. hirta grassland and vineyard soils.

to $7 \mathrm{MgCha}^{-1}$. The opposite land-use change from natural vegetation to agriculture, resulted, after 21 years, in a decrease of $8 \mathrm{MgCha}^{-1}$. Our results confirm that agricultural use strongly modifies soil properties and especially C content (Yan et al., 2012): there is an increase in $C$ content under natural vegetation and less mineralization than in agricultural soil (Novara et al., 


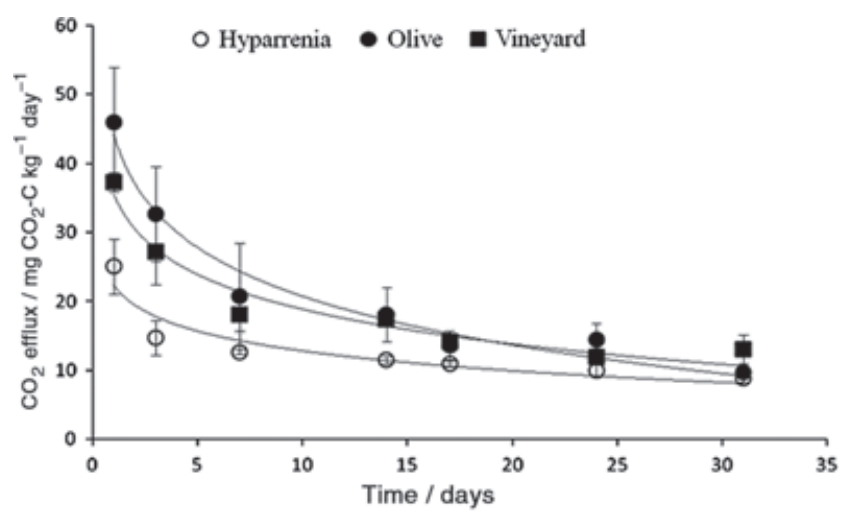

Figure $5 \mathrm{CO}_{2}$ efflux rates over 32 days of incubation for the $H$. hirta grassland, olive grove and vineyard.

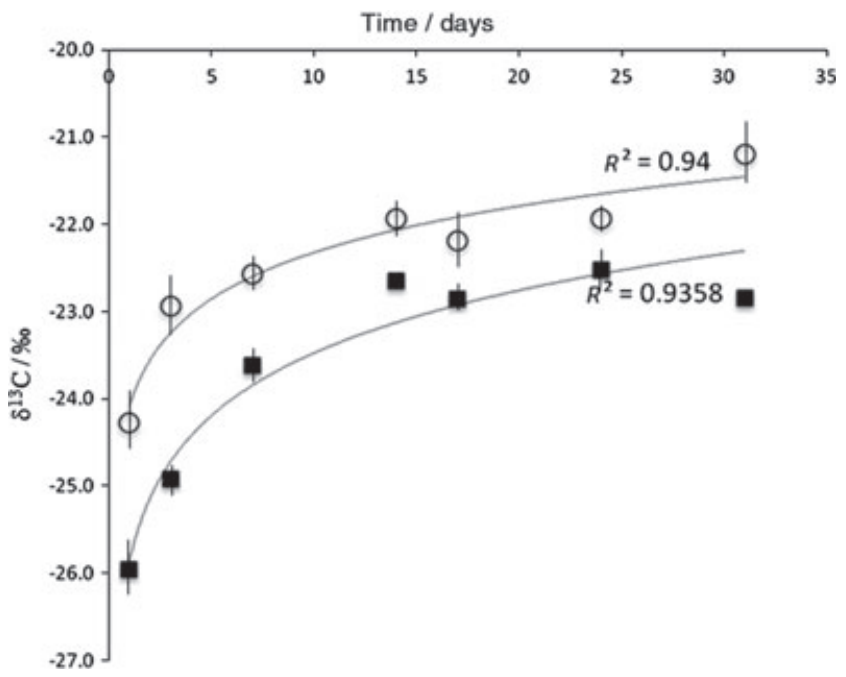

Figure $6{ }^{13} \mathrm{C}$ signature of the evolved $\mathrm{CO}_{2}-\mathrm{C}$ during 32 days of incubation of $\mathrm{C}_{3}-\mathrm{C}_{4}$ (white dots) and $\mathrm{C}_{4}-\mathrm{C}_{3}$ (black dots) soils from the $H$. hirta grassland and vineyard, respectively.

2013). Soil management with continuous tillage of the vineyard and the olive grove in our study, contributed to the removal of spontaneous vegetation growth and more OM mineralization as a consequence of increased aeration, breaking aggregates (Barbera et al., 2012) and making more OM accessible to microbial activity (Solomon et al., 2002). As expected, the increase in C stock under natural vegetation was less than the $\mathrm{C}$ depletion after the vineyard plantation (Lal et al., 2004). The rate of $\mathrm{C}$ increase after abandonment of the olive grove was $0.36 \mathrm{MgC} \mathrm{ha}^{-1}$ year $^{-1}$, while the $\mathrm{C}$ depletion rate was $0.65 \mathrm{MgCha}^{-1}$ year $^{-1}$. These rates of $\mathrm{C}$ accumulation and losses in Mediterranean land use are faster than those described for temperate, boreal and steppe climates (Kurganova \& de Gerenyu, 2008). The greater C depletion rate compared with the $\mathrm{C}$ increase results from intensive soil tillage in the vineyard that can also contribute to $\mathrm{C}$ losses by increasing erosion.
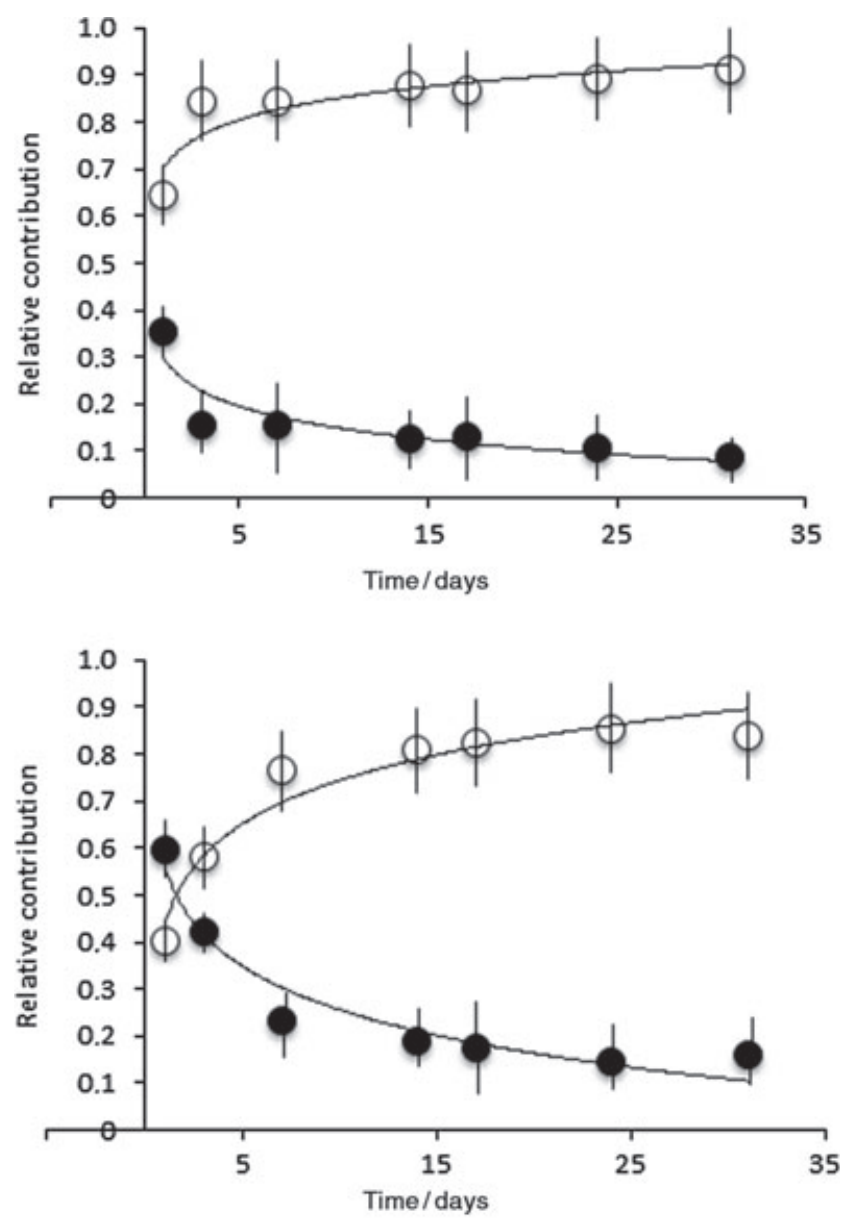

Figure 7 Relative contribution of $\mathrm{C}_{4}-\mathrm{C}$ (white dot) and $\mathrm{C}_{3}-\mathrm{C}$ (black dot) soil during 30 days of incubation of $\mathrm{C}_{3}-\mathrm{C}_{4}$ soil (a) and $\mathrm{C}_{4}-\mathrm{C}_{3}$ soil (b) from $H$. hirta grassland and vineyard, respectively.

Land use affected soil aggregate formation and destruction. In agricultural soil the aggregates are destroyed by cultivation (An et al., 2010), resulting in an increase in the amount of microaggregates. Soil under H. hirta had fewer microaggregates than the agricultural soil. This demonstrates that over 40 years, vegetation change and the consequent SOM increase strongly contribute to formation of macroaggregates. (Majumder et al., 2010). The distribution of SOC between aggregate size fractions in this Mediterranean soil was similar to the pattern observed previously in Sicilian clay soil (Barbera et al ., 2010; Novara et al ., 2012).

Land-use change from olives to $\mathrm{H}$. hirta encouraged $\mathrm{C}$ stabilization in microaggregates and increased $\mathrm{C}$ content in the largest fraction through more litter production under $H$. hirta grassland and subsequent containment in macroagregates. The $\mathrm{C}$ stabilized in the smallest aggregates under $H$. hirta remained after 21 years of vineyard plantation, but $\mathrm{C}$ losses were noted in the largest aggregates. This is connected with the decreases in plant residues under vineyard management that are mainly allocated to the large aggregates (Dorodnikov et al., 2009). 


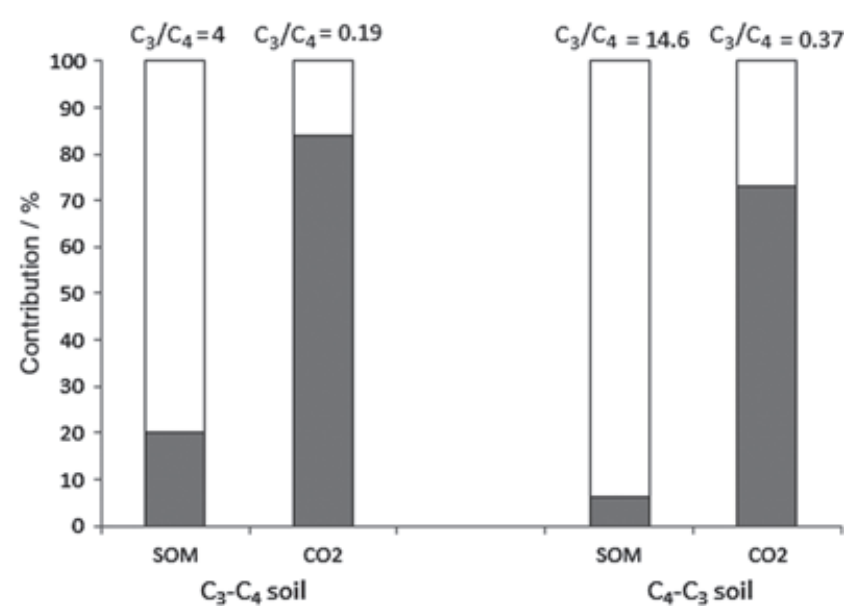

Figure 8 Comparison between the relative contribution of $\mathrm{C}_{4}-\mathrm{C}$ (grey portion) and $\mathrm{C}_{3}-\mathrm{C}$ (white portion) to $\mathrm{SOM}$ and $\mathrm{CO}_{2}$ in $\mathrm{C}_{3}-\mathrm{C}_{4}$ soil $(H$. hirta) and $\mathrm{C}_{4}-\mathrm{C}_{3}$ soil (vineyard).

\section{Stabilization of SOC in soil aggregate size fractions}

Separation of SOC into aggregate size fractions in conjunction with the use of the natural ${ }^{13} \mathrm{C}$ abundance helped us to follow the mechanisms of SOM accumulation and turnover after olive grove$H$. hirta grassland-vineyard succession. Before the fire (40 years ago), the $\mathrm{OM}$ input over a long period was solely of $\mathrm{C}_{3}$ origin. Following the $\mathrm{C}_{4}$ vegetation succession, bulk soil and all fractions were enriched in ${ }^{13} \mathrm{C}$, showing the decay of $\mathrm{C}$ from olive origins and $H$. hirta $\mathrm{C}$ accumulation. After 40 years of natural vegetation development, $80 \%$ of $\mathrm{C}$ derived from the previous crop remained in the soil and most of this was in microaggregates $(<63 \mu \mathrm{m})$ (Figure 4). This indicates that the smallest fraction contained more preserved $\mathrm{OC}$ and retained $\mathrm{C}$ derived from previous vegetation types for longer and more efficiently than the coarser fractions (Desjardins et al., 2006), through physicochemical stabilization. After the land-use change from $H$. hirta grassland to vineyard, most of the $\mathrm{C}$ losses were as $\mathrm{C}_{3}-\mathrm{C}$ and more than $30 \%$ of this $\mathrm{C}_{3}$ $\mathrm{C}$ was lost from the largest aggregates (Figure 4). These results clearly show (i) faster decomposition of new $\mathrm{C}_{3}-\mathrm{C}$ compared with $\mathrm{C}_{4}-\mathrm{C}$ derived from $H$. hirta and (ii) that there was not enough litter input to soil to restore the previous $\mathrm{C}$ content of the biggest aggregates.

\section{$\mathrm{CO}_{2}$ fluxes and their $\delta^{13} \mathrm{C}$ signature during incubation}

The ability of uncultivated soil to retain $\mathrm{C}$ was confirmed by $\mathrm{CO}_{2}$ fluxes over 32 days of incubation. The cumulative $\mathrm{CO}_{2}$ efflux in $H$. hirta soil was 32 and $40 \%$ less than that from the vineyard and olive grove soils, respectively (Figure 5). The $\delta^{13} \mathrm{C}$ signature of evolved $\mathrm{CO}_{2}-\mathrm{C}$ was depleted for all soils, but it was greater for $\mathrm{C}_{3}$ $\mathrm{C}_{4}$ and $\mathrm{C}_{4}-\mathrm{C}_{3}$ soil than for $\mathrm{C}_{3}$ soil. Because the $\mathrm{C}_{3}$ soil reached the isotopic steady-state after 85 years (Blagodatskaya et al., 2011), the difference in $\delta^{13} \mathrm{C}$ between $\mathrm{SOM}$ and $\mathrm{CO}_{2}-\mathrm{C}$ is related to ${ }^{13} \mathrm{C}$ fractionation or preferential use of ${ }^{13} \mathrm{C}$-depleted substances such as lipids or lignin (Werth \& Kuzyakov, 2010).
In the soils after the $\mathrm{C}_{3}-\mathrm{C}_{4}$ and $\mathrm{C}_{4}-\mathrm{C}_{3}$ vegetation change, not only ${ }^{13} \mathrm{C}$ fractionation but also preferential use of recent rather than old $\mathrm{C}$ contributed to $\delta^{13} \mathrm{C}$ enrichment in $\mathrm{CO}_{2}$. This means that less stabilized younger organic materials (having $\mathrm{C}_{4}$ or $\mathrm{C}_{3}$ signature for $\mathrm{C}_{3}-\mathrm{C}_{4}$ and $\mathrm{C}_{4}-\mathrm{C}_{3}$ soils, respectively) will be preferred for microbial utilization and consequently contribute strongly to $\mathrm{CO}_{2}$ evolution.

The relative contribution of $\mathrm{C}_{4}-\mathrm{C}$ to the evolved $\mathrm{CO}_{2}$ was always more than $60 \%$ in $\mathrm{C}_{3}-\mathrm{C}_{4}$ soil, and increased during incubation as in other studies (Blagodatskaya et al., 2011). Although the relative contribution of $\mathrm{C}_{4}-\mathrm{C}$ to $\mathrm{SOC}$ was less than the $\mathrm{C}_{3}-\mathrm{C}$ contribution, this $\mathrm{C}_{4}$ portion of organic matter in the $H$. hirta soil represents the new $\mathrm{C}$, which was less stabilized and therefore more available for microbial use. The increase in the contribution of $\mathrm{C}_{4}-\mathrm{C}$ during incubation can be related to microbial activity. It has been observed in short-term incubation studies that in the earlier stage of incubation the total microbial biomass decreased because of disturbance and the absence of new $\mathrm{C}$ inputs. After the initial period, the subsequent microbial population uses metabolites remaining after the first stage and, in this case, decomposition of microbial tissue led to an enrichment of the respired $\mathrm{CO}_{2}-\mathrm{C}$ (Blagodatskaya et al., 2011).

The contribution of $\mathrm{C}_{4}-\mathrm{C}$ to the total $\mathrm{CO}_{2}$ efflux in $\mathrm{C}_{4}-\mathrm{C}_{3}$ soil was less than the $\mathrm{C}_{3}-\mathrm{C}$ contribution in the first few days, but increased during the incubation period. However, the relative contribution of $\mathrm{C}_{4}-\mathrm{C}$ was less in the $\mathrm{C}_{3}-\mathrm{C}_{4}$ soil than in the $\mathrm{C}_{4}$ $\mathrm{C}_{3}$ soil because of preferential use of new $\mathrm{C}\left(\mathrm{C}_{3}-\mathrm{C}\right)$. The ratio between $\mathrm{C}_{3}-\mathrm{C}$ and $\mathrm{C}_{4}-\mathrm{C}$ in $\mathrm{CO}_{2}$ was, for both land uses, less than that in the SOM. The $\mathrm{CO}_{2}$ emission had therefore originated mainly from $\mathrm{H}$. hirta (Figure 8). The ratio between $\mathrm{C}_{3}-\mathrm{C}$ in $\mathrm{CO}_{2}$ and $\mathrm{C}_{3}-\mathrm{C}$ in $\mathrm{SOM}$ was similar in the two soils, whilst that between $\mathrm{C}_{4}-\mathrm{C}$ in $\mathrm{CO}_{2}$ and $\mathrm{C}_{4}-\mathrm{C}$ in $\mathrm{SOM}$ was greater in $\mathrm{C}_{4}-\mathrm{C}_{3}$ soil. The $\mathrm{C}$ of $\mathrm{OM}$ derived from $\mathrm{H}$. hirta vegetation was therefore more degradable in $\mathrm{C}_{4}-\mathrm{C}_{3}$ soil.

\section{Turnover of recent and old carbon}

The $\mathrm{C}$ turnover in soil under $H$. hirta was about 10 times faster than in that under the olive grove. The reasons for this difference are: (i) the biomass of $H$. hirta is younger than that from olives, which was added to the soil more than four decades before, and therefore is more easily mineralizable; and (ii) the SOC in the olive grove was mainly stored in the smallest aggregates and was therefore more stable. According to Equation (6), the MRT of $\mathrm{C}$ decomposed to $\mathrm{CO}_{2}$ within 1 month was 30 days for H. hirta soil and 17 days for olive grove soil. Results of MRT showed differences between the two estimation approaches: the MRT of $H$. hirta was less in the first approach and more in the second approach than that of the olive grove. The main difference is that the first approach, using $\delta^{13} \mathrm{C}$ isotopic signature shift in SOM after $\mathrm{C}_{3}-\mathrm{C}_{4}$ vegetation change, estimates the MRT value only of $\mathrm{C}_{4}$ organic matter, while the second approach estimated the MRT of $\mathrm{C}_{3}-\mathrm{C}_{4}$ soil under $H$. hirta. If only the portion $\mathrm{C}_{4}-\mathrm{C}$ of total $\mathrm{SOC}$ in $H$. hirta is considered, the MRT 
is approximately 6 days and therefore less than that for the olive grove soil.

\section{Conclusion}

This study highlighted the effect of land-use change on SOC stock and $\mathrm{OM}$ dynamics in a Mediterranean area using natural differences in $\delta^{13} \mathrm{C}$ of plants with $\mathrm{C}_{3}$ and $\mathrm{C}_{4}$ photosynthesis. We demonstrated that (i) intensive agriculture (olives and vines) in the Mediterranean region has a negative impact on $\mathrm{C}$ sequestration when compared with semi-natural vegetation; (ii) vegetation change to $H$. hirta and consequent SOM increase strongly contribute to the formation of macroaggregates from microaggregates and (iii) turnover of SOM under $H$. hirta was quicker than under olives, but soils under natural vegetation emit less $\mathrm{CO}_{2}$ and therefore are able to sequester more SOC. Consequently, we strongly recommend sustainable management practices to avoid SOM decrease and soil erosion. We suggest the application of organic fertilizers as well as promoting the growth of natural grasses in the winter period or burying pruning residues to contribute to $\mathrm{C}$ input and decrease erosion.

\section{Acknowledgements}

This work was financially supported by the PRIN project 'The impacts of secondary succession processes on carbon storage in soil and biomass and on biodiversity and the role of dispersal centers and vectors for recolonization processes'. We thank F. Fiordilino for technical support during the research.

\section{References}

An, S., Mentler, A., Meuer, H. \& Blum, W.E.H. 2010. Soil aggregation, aggregate stability, organic carbon and nitrogen in different soil aggregate fractions under forest and shrub vegegation on the Loess Plateau, China. Catena, 81, 226-233.

Barbera, V., Poma, I., Gristina, L., Novara, A. \& Egli, M. 2012. Longterm cropping systems and tillage management effects on soil organic carbon stock and steady state level of $\mathrm{C}$ sequestration rates in a semiarid environment. Land Degradation \& Development, 23, 82-91.

Bai, E., Boutton, T.W., Liu, F., Wu, X.B., Hallmark, C.T. \& Archer, S.R. 2012. Spatial variation of soil $\delta 13 \mathrm{C}$ and its relation to carbon input and soil texture in a subtropical lowland woodland. Soil Biology \& Biochemistry, 44, 102-112.

Balesdent, J. \& Mariotti, A. 1996. Measurement of soil organic matter turnover using $13 \mathrm{C}$ natural abundance. In: Mass Spectrometry of Soils (eds T.W. Button \& S. Yamasaki), pp. 83-111. Marcel Dekker, New York.

Barbera, V., Poma, I., Gristina, L., Novara, A. \& Egli, M. 2012. Longterm cropping systems and tillage management effects on soil organic carbon stock and steady state level of $\mathrm{C}$ sequestration rates in a semiarid environment. Land Degradation \& Development, 23, 82-91.

Blagodatskaya, E., Yuyukina, T., Blagodatsky, S. \& Kuzyakov, Y. 2011. Turnover of soil organic matter and microbial biomass under C3 - C4 vegetation change: consideration of $13 \mathrm{C}$ fractionation and preferential substrate utilization. Soil Biology \& Biochemistry, 43, 159-166.
Blake, G.R. \& Hartge, K.H. 1986. Bulk density. In: Methods of Soil Analysis, Part 1. Volume 9: Agronomy Monograph, 2nd edn (ed A. Klute), pp. 363-375. American Society of Agronomy, Madison, WI.

Botha, C.E.J. \& Russell, S. 1988. Comparison of photosynthetic temperature and light optima in selected $\mathrm{C} 3$ and $\mathrm{C} 4$ grasses from the $\mathrm{E}$. Cape/Ciskei region. South African Journal of Botany, 54, 133-136.

Carrera, A.L., Mazzarino, M.J., Bertiller, M.B., del Valle, H.F. \& Carretero, E.M. 2009. Erratum to plant impacts on nitrogen and carbon cycling in the Monte Phytogeographical Province, Argentina. Journal of Arid Environments, 73, 192-201.

Chejara, V.K., Kristiansen, P., Whalley, R.D.B., Sindel, B.M. \& Nadolny, C. 2008. Factors affecting germination of Coolatai Grass (Hyparrhenia hirta). Weed Science, 56, 543-548.

Cornelissen, G., Kukulska, Z., Kalaitzidis, S., Christanis, K. \& Gustafsson, O. 2004. Relations between environmental black carbon sorption and geochemical sorbent characteristics. Environmental Science \& Technology, 38, 3632-3640.

Derrien, D. \& Amelung, W. 2011. Computing the mean residence time of soil carbon fractions using stable isotopes: impacts of the model framework. European Journal of Soil Science, 62, 237-252.

Desjardins, T., Folgarait, P.J., Pando-Bahuon, A., Girardin, C. \& Lavelle, P. 2006. Soil organic matter dynamics along a rice chronosequence in north-eastern Argentina: evidence from natural 13C abundance and particle size fractionation. Soil Biology \& Biochemistry, 38, 2753-2761.

Dinesh, R., Chaudhuri, S.G., Ganeshamurthy, A.N. \& Dey, C. 2003. Changes in soil microbial indices and their relationships following deforestation and cultivation in wet tropical forests. Applied Soil Ecology, 24, 17-26.

Dorodnikov, M., Blagodatskaya, E., Blagodatsky, S., Marhan, S., Fangmeier, A. \& Kuzyakov, Y. 2009. Stimulation of microbial extracellular enzyme activities by elevated $\mathrm{CO}_{2}$ depends on aggregate size. Global Change Biology, 15, 1603-1614.

Dorodnikov, M., Kuzyakov, Y., Fangmeier, A. \& Wiesenberg, G.L.B. 2011. $\mathrm{C}$ and $\mathrm{N}$ in soil organic matter density fractions under elevated $\mathrm{CO}_{2}$ : turnover vs. stabilization. Soil Biology \& Biochemistry, 43, 579-589.

Gavrichkova, O., Moscatelli, M.C., Kuzyakov, Y., Grego, S. \& Valentini, R. 2010. Defoliation decreases soil respiration and microbial activity in a Mediterranean grassland. Agriculture, Ecosystems \& Environment, 136, 87-96.

Gearing, J.N. 1991. The study of diet and trophic relationships through natural abundance ${ }^{13} \mathrm{C}$. In: Carbon Isotope Techniques (eds D.C. Coleman \& B. Fry), pp. 363-375, pp. 201-218. Academic Press, San Diego, CA.

Jolivet, L., Faccenna, C., Goffe, B., Burov, E. \& Agard, P. 2003. Subduction tectonics and exhumation of high-pressure metamorphic rocks in the Mediterranean orogens. American Journal of Science, 303, 353-409.

Kurganova, I.N. \& de Gerenyu, V.O.L. 2008. Assessment and prediction of changes in the reserves of organic carbon in abandoned soils of European Russia in 1990-2020. Eurasian Soil Science, 41, 1371-1377.

Kurganova, I.N., de Gerenyu, V.O.L., Shvidenko, A.Z. \& Sapozhnikov, P.M. 2010. Changes in the organic carbon pool of abandoned soils in Russia (1990-2004). Eurasian Soil Science, 43, 333-340.

Lal, R., Griffin, M., Apt, J., Lave, L. \& Morgan, M.G. 2004. Managing soil carbon. Ecology Science, 304, 393.

Laudicina, V.A., Badalucco, L. \& Palazzolo, E. 2011. Effect of compost input and tillage intensity on soil microbial biomass and activity under Mediterranean conditions. Biology \& Fertility of Soils, 47, 63-70. 
Loumou, A. \& Giourga, C. 2003. Olive groves: "The life and identity of the Mediterranean". Agriculture \& Human Values, 20, 87-95.

Majumder, B., Ruehlmann, J. \& Kuzyakov, Y. 2010. Effects of aggregation processes on distribution of aggregate size fractions and organic C content of a long-term fertilized soil. European Journal of Soil Biology, 46, 365-370.

Novara, A., La Mantia, T., Barbera, V. \& Gristina, L. 2012. Paired-site approach for studying soil organic carbon dynamics in a Mediterranean semiarid environment. Catena, 89, 1-7. doi: 10.1016/J.Catena.2011.09.008

Novara, A., Gristina, L., La Mantia, T. \& Rhul, J. 2013. Carbon dynamics of soil organic matter in bulk soil and aggregate fraction during secondary succession in a Mediterranean environment. Geoderma, 193-194, 213-221.

Robertson, G.P., Wedin, D., Groffman, P.M., Blair, J.M., Holland, E.A., Nadelhoffer, K.J., et al. 1999. Soil carbon and nitrogen availability. In: Standard Soil Methods for Long-Term Ecological Research (eds G.P. Robertson, D.C. Coleman, C.S. Bledsoe \& P. Sollins), pp. 258-271. Oxford University Press, New York.

SAS Institute 2001. SAS/STAT, Release 8.01. SAS Institute, Cary, NC.

Schneckenberger, K. \& Kuzyakov, Y. 2007. Carbon sequestration under Miscanthus in sandy and loamy soils estimated by natural $13 \mathrm{C}$ abundance. Journal of Plant Nutrition \& Soil Science, 170, 538-542.

Shang, C. \& Tiessen, H. 2000. Carbon Turnover and Carbon-13 Natural Abundance in Organo-mineral Fractions of a Tropical Dry Forest Soil Under Cultivation. Soil Science Society of America Journal, 64, 2149-2155.

Solomon, D., Fritzsche, F., Lehmann, J., Tekalign, M. \& Zech, W. 2002. Soil organic matter dynamics in the subhumid agroecosystems of the Ethiopian highlands: evidence from natural C-13 abundance and particle-size fractionation. Soil Science Society of America Journal, 66, 969-978.
Thornthwaite, C.W. \& Mather, J.R. 1955. The Water Balance. Publications in Climatology: Volume 8. Laboratory for Climatology, Centerton, NJ.

Ussiri, D.A. \& Johnson, C.E. 2003. Characterization of organic matter in a northern hardwood forest soil by 13C NMR and chemical methods. Geoderma, 111, 123-149.

Vinton, M.A. \& Burke, I.C. 1995. Interactions between individual plant species and soil nutrient status in short-grass-steppe. Ecology, 76, 1116-1133.

von Lützow, M., Kögel-Knabner, I., Ekschmitt, K., Matzner, E., Guggenberger, G., Marschner, B., et al. 2006. Mechanisms for organic matter stabilization in temperate soils - a synthesis. European Journal of Soil Science, 57, 426-445.

Werth, M. \& Kuzyakov, Y. 2008. Determining root-derived carbon in soil respiration and microbial biomass using $14 \mathrm{C}$ and 13C. Soil Biology \& Biochemistry, 40, 625-637.

Werth, M. \& Kuzyakov, Y. 2010. 13C fractionation at the rootmicroorganisms-soil interface: a review and outlook for partitioning studies. Soil Biology \& Biochemistry, 42, 1372-1384.

WRB 2006. World Reference Base for Soil Resources - A Framework for International Classification, Correlation and Communication. World Soil Resources Reports 103, International Union of Soil Sciences, ISRIC World Soil Information and Food and Agriculture Organization of the United Nations, Rome.

Yan, Y., Tian, J., Fan, M., Zhang, F., Li, X., Christie, P., et al. 2012. Soil organic carbon and total nitrogen in intensively managed arable soils. Agriculture, Ecosystems \& Environment, 159, 102-110.

Zibilske, M.L. 1994. Carbon mineralization. In: Methods of Soil Analysis . Part 2 - Microbiological and Biochemical Properties. Soil Science Society of America Book Series Number 5 (eds R.W. Weaver, S. Angle, P. Bottomley, D. Bezdicek, S. Smith, A. Tabatabai, et al.). Soil Science Society of America, Madison, WI. pp. 835-863. 